\title{
Foreword: learning history
}

\section{Edward Friedman ${ }^{1}$}

Learning about Taiwan has led me to re-think history. A study of commerce in the West Pacific and Indian Oceans from 1620 to $1720^{2}$ reveals that Taiwan and Hokkien people were a key hub of early modern maritime networks. They were central to the burgeoning world market. In addition, as detailed in the chapter by Doris T. Chang, Taiwan has been a leader in gender equality. Democratic Taiwan has a dynamic civil society. Also, as everybody knows, Taiwan has won international acclaim for its twenty-first-century success in containing the COVID-19 pandemic. Taiwan, the size of Massachusetts plus Rhode Island, continually surprises me with its world-class achievements.

I first flew into Taipei, the capital of Taiwan, in 1964. I met fellow graduate students who intended to study the Chinese peasantry by going to villages on the island, which was just south of the Japanese island chain and just north of the Philippines island chain and 100 miles east of the continent of Asia across a deep-water strait.

Social scientists assumed that, since the PRC (People's Republic of China) was closed-off to researchers by Mao Zedong's Leninist-Stalinist dictatorship, international scholars could best study the Chinese countryside, then home to 80 percent or so of the population of the PRC, by studying Taiwanese villagers. These excellent scholars did not fully appreciate what had long made Taiwan distinct.

Wang-you Chou's chapter details how much more involved Taiwan's farm families were with the world economy. The Taiwanese also were much better educated than the village households in guerrilla era Mao's base in China's northwest hinterland. Most Taiwanese, Minnan language speakers of the Hokkien community, fled to Taiwan from highly commercialized Fujian province to escape cruel treatment by the Manchu military of the new Qing empire, which had in 1644 replaced the Sinicized Ming empire. These Hokkien Taiwanese, who began as commercialized Ming loyalists in the seventeenth

1 Professor Emeritus in the Department of Political Science at the University of Wisconsin; specializes in PRC foreign policy and village politics in the PRC.

2 Xing Hang, Conflict and Commerce in Maritime East Asia, Cambridge: Cambridge University Press, 2015. 
century, joined Hokkien settlers who had come to Taiwan earlier in the seventeenth century to work in new Dutch plantations. The militarily powerful Qing state, however, soon incorporated Taiwan late in the seventeenth century.

The Qing empire, two centuries later, surrendered Taiwan to Meiji Japan after the Qing lost an 1894/1895 clash with the Meiji fought over imperial control of Korea. When a U.S.-led WW II coalition defeated Hirohito's imperial military in 1945, Chiang Kai-shek's ROC (Republic of China) sent soldiers to Taiwan to accept Japan's surrender. Over the prior half-century, as detailed in the chapters by Yin-Chen Kang and many other contributors to this volume, Taiwanese had been somewhat Japanized. This too made Taiwanese unlike Mao's Chinese peasant base. My 1964 colleagues erred in thinking that studying Taiwanese farm households could reveal important truths about the hinterland peasants fighting in Mao's armies in a Chinese civil war.

Already in the seventeenth century, Confucian Ming loyalist Hokkien settlers of Taiwan, as Confucian Koreans and Confucian Japanese, imagined the Manchu warriors who founded a gunpowder empire of the Qing as Tartar barbarians. In contrast to these purportedly uncivilized shamanists who spoke a Siberian tongue, Koreans, Japanese and Taiwanese Confucians imagined themselves as the center of civilization, as Zhongguo, surely not Manchu barbarians (when Chinese Buddhists first went to India to copy the Sutras, they referred to India as Zhongguo, the center of civilization). It would be another 250 years before Zhongguo was understood on the Sinified Asian continent to mean a Chinese nation-state. ${ }^{3}$ Identity on Taiwan has long been a complex and contested matter. In 1964, researchers were not fully aware of the conflictful particularities of Taiwan identity formation.

Chiang Kai-shek's ROC government, which ruled Taiwan after losing a civil war to Mao's military in 1949 and moving to Taiwan, legitimated itself on Taiwan as China. It held the China seat on the U.N. Security Council. In contrast to Mao's atheist regime, which treated Confucianism as a reactionary obstacle to revolution, an ideology that had to be wiped out by Mao's regime, Chiang's government promoted Confucianism, the presumed essence of civilization and, therefore, imagined itself as the authentic China. But, in contrast to my 1964 fellow graduate students arriving in Taiwan, Chiang did not see Taiwanese, with their unique experiences, as Chinese. This history surprised me.

When I first landed in Taipei, Chiang's police boarded the newly arrived plane and confiscated all material written in Japanese. I was perplexed when they seized a Japanese language issue of Reader's Digest since that journal

3 Bill Hayton, The Invention of China, New Haven, CT: Yale University Press, 2020. 
was a strong supporter of Chiang. To Chiang, however, Taiwanese had, under Japan's colonial rule been Japanized. They now had to be de-Japanized. Chiang's goal was to Sinicize the Taiwanese. Chiang did not see Taiwanese villagers as Chinese peasants.

As the chapters by Frank Hsiao and many others illuminate, it was a fact that, going back to the Tokugawa reign in Japan, when Hokkien trade networks were deeply embedded in the port of Nagasaki, ties to Japan were important to the Taiwanese. Koxinga, whose largely Hokkien military defeated the Dutch on Taiwan in the seventeenth century, was born in Japan to a Japanese mother. Yet, as noted earlier, Hokkien on Taiwan also were Ming loyalist Confucians. Taiwan identity has long incorporated multiple influences.

Taiwan's economic modernization, making it second only to Japan in Asian wealth by the end of Taiwan's existence as a colony of Japan, owed a lot to Japanese policies, as shown in the chapters by Peter Chow and other authors. More surprisingly, as revealed in the chapters by Michael Hsiao, Abraham Lin and others, Japanese policies unintentionally unleashed on Taiwan a growing consciousness among Taiwanese that they actually were neither Chinese nor Japanese. Taiwan increasingly was imagined as a unique place with its own destiny. People on Taiwan were Taiwanese, They adopted, adapted and localized cultural elements from Europe, the Hokkien community, Japan, Ming China, Hakka settlers and indigenous Austronesians. Taiwanese were profoundly multicultural.

State and society in Taiwan were not always in harmony. Under barbarian Qing rule, Confucian Taiwanese were supposed to imagine themselves as Qingren, people loyal to the ruling Manchu Aisingioro imperial lineage. As part of the Japanese empire, the Taiwanese were supposed to be loyal to the world's longest-lasting imperial lineage, which headed an Asian state widely admired for its incredibly rapid modernization. It would not be until the twentieth century that Taiwanese who had long identified with communities premised on a language, a lineage or a temple could identify with a passionate Taiwan-wide nationalism. Modern nationalism is a uniquely powerful identity far deeper than identities with distant, alien imperial lineages.

A secure, democratic Taiwan nation, however complex the recent evolution of its democratic Taiwanese identity, as shown by Shiau-Chi Shen, can imagine itself as a rich, multicultural democratic society as the inevitable result of a deep and long history going back centuries. Such a national identity can absorb or deflect challenging events rather than be changed or undermined by them. It becomes a given that Taiwanese are multicultural democrats. As the American writer William Faulkner described the persistent and preservative power of cultural identity, "Memory believes before knowing remembers."

To Chiang's KMT, however, Japanized Taiwanese were traitors. They had served Hirohito's military empire as soldiers and administrators. For Chiang, 
it was imperative that Japanized Taiwanese be Sinified, be Han-hua, become civilized, a notion similar to Taiwan's formative anti-Manchu Confucian consciousness.

To the Mainlander, anti-Japan Nationalists (KMT, Kuomintang) who started coming to Taiwan in 1945, Japanese were cruel invaders of the ROC whose brutal occupation from 1931 to 1945 had facilitated the 1949 civil war victory of the armies of Mao's CCP (Chinese Communist Party) despite the enormous sacrifice of life by the KMT military in bravely resisting Hirohito's military aggression.

For the Mainlanders, the non-Chinese Taiwanese were not civilized. They had not become Hanhua, civilized Chinese, while Chinese, in contrast, had inherited a great ancient civilization. Taiwanese were imagined as primitive, an understanding that could not appreciate how Hokkien actually had long experienced themselves as uniquely civilized, going back to the age of Koxinga. Taiwanese experienced the Mainlander losers who fled to Taiwan after World War II as poor, undisciplined, corrupt, irrational, violent and backward. A clash between the two communities exploded on February 28, 1947. The KMT military imprisoned, tortured and slaughtered the civilian Taiwanese elite. Clearly, Taiwanese history was not Chinese history.

This clash of identities in which the Mainlander KMT looked down on the Hokkien community pervaded the Taiwan I lived in during 1964, 1965 and 1966. It was quotidian. If I walked with a Mainlander colleague and came across a beautiful flower and commented, "What a beautiful flower," the Mainlander immediately chided me: "Beautiful flower? Beautiful flower? There are no beautiful flowers on Taiwan. If you want to see a beautiful flower, go to the Mainland. China has beautiful flowers."

To Mainlanders, Taiwan lacked magnificence. It lacked civilization. Into the twenty-first century, many Mainlanders still hold this view. In the academy on Taiwan, many Mainlanders resist a curriculum that includes Taiwan culture. They don't think Taiwan has much of a culture. They certainly could not appreciate a Taiwanese understanding of Hokkien Taiwanese as "the civilized" in contrast both to barbarian Manchu and to the violent and irrational Mainlanders.

And yet, gradually, over a century, but especially since democratization began in 1988, a multicultural Taiwanese identity has come to pervade all the nation's communities - Hokkien, Mainlanders, Hakka and Indigenous. The twenty-first-century CCP, however, understands this history of identity formation and transformation on Taiwan - from Ming to Qing to Japanese to KMT Chinese to multicultural Taiwanese - to suggest that, once the expansionist PRC annexes democratic, multicultural Taiwan, the Taiwanese will accept being superior Han Chinese as promoted by the CCP state. In this CCP view, 
the state is all-powerful. There indeed is much evidence that a totalitarian state can terrorize most of its subjects into conformity and complicity.

But Taiwan's new multicultural, democratic national identity is different from prior imperial or cultural identities and quite deep. In the Japanese colonial era, Hokkien speakers became aware that their mother tongue was painfully and unjustly marginalized by Japanese colonizers. Railing against the imperial occupier, Taiwanese sought self-rule. By the end of the 1930s, Mao's CCP supported a Taiwanese national liberation movement seeking independence from Hirohito's Showa era military empire. Taiwanese were and should be a nation.

Despite Chiang's subsequent policy of coerced Sinicization, indeed, in part in response to this coerced Sinicization, as Kang and others point out, a sense of being Taiwanese deepened and spread. The Chinese KMT dictatorship banned the Hokkien community's Minnan language from many venues. Hokkien children regularly returned home from school reporting humiliating mistreatment by teachers for speaking their mother tongue. Mainlanders who grew up speaking Mandarin were privileged.

I experienced this Taiwanese resentment of Sinicization at a rural wedding I attended in 1965. In the groom's family where I joined a wedding banquet, I heard how Grandma stayed home to care for the little children who were too young for kindergarten, but she was kept from hearing her mother tongue, Hokkien, on the radio because of KMT language policy. The family was furious at the pain the Mainlanders inflicted on Grandma. Justice required embracing Taiwanese-ness and ending a prejudiced Sinic system that peripheralized the majority Hokkien community on Taiwan.

A Chinese identity for Taiwan further lost its attractiveness in 1971-1972 when President Richard Nixon began normalizing USA relations with the PRC and Chiang's government lost its seat representing China in the U.N. Taiwanese, including Mainlanders, began to re-think their historical roots. Some came to identity with Mao's supposedly proletarian movement. But far more Taiwanese focused on Taiwan's original settlers, the indigenous Austronesians whose language communities were spread from the South Pacific Islands to Madagascar at the western edge of the Indian Ocean, an identity having nothing in common with land-focused continental Chinese such as Mao's peasantry. Taiwan's history began on Taiwan. In contrast to most studies of Taiwan and most other countries, this volume has a chapter that tells the story of Taiwan's indigenous communities. In fact, since democratization began in 1988, Taiwan has practiced one of the world's most enlightened first people's policies.

I ran into indigenous Austronesian resentment of the Hokkien in 1966. I had joined a group of Mainland KMT stalwarts on a mailboat heading from Taitung on Taiwan's Pacific Ocean east coast to Austronesian Orchid 
Island and to Green Island, which held Taiwanese political prisoners going back at least to the $2 / 28$ insurrection. During my short stay on Orchid Island, teenage Austronesian males, who had come out on the bay where the mailboat anchored, to row us to shore in a large outrigger canoe, returned at night to the elementary school gym on whose floor I was preparing to sleep (the island had no hotels or boarding houses). They were part of the modern world. They wore sneakers and were tied to the world by transistor radios. They wanted to know when the U.S. Marines would be returning to liberate indigenous people from the Mainlanders, by which term they meant the Hokkien who drove them from their land in the seventeenth century. Those U.S. Marines had stopped momentarily on Orchid Island in 1945 heading north to finish off Hirohito's Empire, which then ruled Taiwan.

Historical identity formation has long-term consequences. Opposed to Hokkien settler colonialism since the seventeenth century, Taiwan's indigenous people tend to not vote today for the Hokkien-majority Democratic Progressive Party despite Taiwan's multicultural democratic inclusivity, a world away from Han China's genocidal amalgamationism meant to extinguish the cultural essence of minority identities in East Turkestan, Tibet and Inner Mongolia. Taiwan is not China. It promotes human rights for all its people. In Taiwan, Christians, Buddhists, Taoists, Confucians and Indigenous all thrive.

However, CCP irredentism threatens Taiwan's historical humane achievements. PRC chauvinistic irredentism threatens to annex Taiwan, as detailed in June Dreyer's chapter. The inhumanity unleashed by the neo-totalitarian CCP against people in the PRC, from Uyghurs to the citizens of Hong Kong, has been well covered by the international media. The CCP also seeks to replace Taiwan's vibrant multiculturalism with Han racism.

What is at stake is not just the fate of 24 million free Taiwanese. Han CCP ambitions, as Dreyer shows, are region-wide. And because the Indo-Pacific is the world's most economically dynamic region, what threatens Taiwan is also a matter of global significance. The history of Taiwan, as revealed in the rich chapters of this broad-ranging, scholarly book, has long been, and continues to be, a matter of global significance. 